\title{
NFкB1 (p50)-deficient mice are not susceptible to multiple low-dose streptozotocin-induced diabetes
}

\author{
J G Mabley ${ }^{1}$, G Haskó ${ }^{2}$, L Liaudet ${ }^{1,2}$, F Soriano ${ }^{1,2}$, G J Southan ${ }^{1}$, \\ A L Salzman ${ }^{1}$ and C Szabó ${ }^{1}$ \\ ${ }^{1}$ Inotek Corporation, Suite 419E, 100 Cummings Center, Beverly, MA 01915, USA \\ ${ }^{2}$ Department of Surgery, New Jersey Medical School, UMDNJ, Newark, NJ 01703, USA \\ (Requests for offprints should be addressed to J Mabley; Email: jmabley@inotekcorp.com)
}

\begin{abstract}
Insulin-dependent diabetes mellitus (IDDM) is a disease characterized by the autoimmune destruction of the pancreatic $\beta$-cells, which requires the expression of a number of immune-related genes including major histocompatibility complex proteins, cytokines, chemokines, and cytotoxic enzymes, many of which are regulated by the transcription factor, NFKB. Inhibition of the entire NFKB family of transcription factors may be harmful, as these factors are involved in many normal physiological processes. However, identifying and targeting specific NFKB subunits critical for the pathogenesis of disease may prove to be valuable in designing new therapeutic strategies. To assess the potential role of the NFKB subunit, p50, in the development of IDDM, mice with gene disruption for NFKB (p50) were investigated for susceptibility to IDDM. We found that p50-deficient mice were fully resistant against multiple low-dose streptozotocin-induced dia-
\end{abstract}

betes, a model of diabetes with a strong autoimmune component. The site of involvement of NFKB (p50) lies at an early, critical juncture of immune activation and proinflammatory mediator production, because: (1) isolated islets of Langerhans from NFKB (p50)-deficient mice were not protected from the islet dysfunction induced by in vitro application of proinflammatory cytokines; (2) p50-deficient mice were not resistant to diabetes induced by a single high dose of streptozotocin, a model with a large oxidant component and no autoimmune involvement; and (3) diabetes induced up-regulation of nitric oxide and interleukin-12 was blocked in the p50-deficient mice. Our data suggest that NFKB (p50) has an essential role in the development of autoimmune diabetes. Selective therapeutic blockade of this subunit may be beneficial in preventing IDDM.

Journal of Endocrinology (2002) 173, 457-464

\section{Introduction}

Insulin-dependent diabetes mellitus (IDDM) is characterized by the selective destruction, via an autoimmune process, of the insulin-secreting $\beta$-cells in the pancreatic islets of Langerhans. Development of an autoimmune disease such as IDDM requires expression of a number of immune-related genes such as those which encode cytokines (tumour necrosis factor alpha (TNF $\alpha$ ) and interleukin (IL)-1; Rabinovitch \& Suarez-Pinzon 1998), chemokines (Bradley et al. 1999), adhesion molecules (vascular cell adhesion molecule-1 and intercellular cell adhesion molecule (ICAM; Bradley et al. 1999), costimulatory molecules (Karlsson et al. 2000) and cytotoxic enzymes (inducible nitric oxide synthase (iNOS) and cyclo-oxygenase (COX)-2; Eizirik et al. 1996). These proteins have crucial roles in the activation, migration and effector functions of inflammatory cells. Their expression is regulated by various transcription factor families, including the NFKB/Rel family.
The NFkB/Rel family of proteins consists of at least five

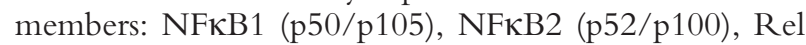
A (p65), Rel B and c-Rel (Tak \& Firestein 2001). In unstimulated cells $\mathrm{NFKB}$ is primarily located in the cytoplasm as inactive homo- or heterodimeric proteins associated with an inhibitory protein termed IKB (Tak \& Firestein 2001). Proinflammatory stimuli, cytokines, free radicals, and viral and bacterial products activate NFKB by phosphorylation and proteolytic degradation of the IKB subunit, leading to translocation of NFKB to the nucleus, where it binds to the $\mathrm{\kappa B}$ sites of gene promoters (Chen et al. 1999, Janssen-Heininger et al. 2000). Immune-related gene promoter regions that contain the $\mathrm{\kappa B}$ binding site include major histocompatibility complex molecules, proinflammatory cytokines (e.g. TNF $\alpha$, IL-1 $\beta$ ), proinflammatory enzymes such as iNOS and inducible COX, and apoptosis-related molecules (such as Fas and FasL) (Baeuerle \& Henkel 1994, Barnes \& Karin 1997).

Much of our information about the role of NFKB in diabetes and has come from in vitro experiments showing a 
critical role of this factor in cytokine-mediated destruction of islet cells (Flodstrom et al. 1996, Giannoukakis et al. 2000). In vivo, however, it is more difficult to define the role of this ubiquitous transcription factor, as NFKB has a key role in many physiological functions. Immunosuppressive agents such as glucocorticoids, FK506 and cyclosporin A, used to prevent IDDM in animal models, have all been shown to inhibit NFKB activation, along with their other actions (Beauparlant \& Hiscott 1996). It has been reported that an NFKB decoy oligodeoxynucleotide injected intravenously inhibits diabetogenesis and $\mathrm{NFKB}$ activation by alloxan in mice (Grankvist et al. 1981, Quan et al. 2001). The activation of NFKB and destruction of islet $\beta$-cells by alloxan is, however, likely to be a direct effect of alloxan, which is an oxygen free-radical generator, and to have no autoimmune component.

Therefore, in order to evaluate the specific role of NFKB1 (p50) in IDDM pathogenesis, we utilized NFKB (p50)-deficient mice (Sha et al. 1995) and determined their sensitivity to streptozotocin-induced diabetes. Streptozotocin is a specific $\beta$-cell toxin and can be used to induce diabetes chemically in rats and mice. Streptozotocin is taken up by the $\beta$-cells through the glucose transporter, Glut-2 (Schnedl et al. 1994, Elsner et al. 2000), where it decomposes intracellularly, causing DNA damage directly, by alkylation (Delaney et al. 1995, Elsner et al. 2000), and indirectly, via generation of nitric oxide (NO) (Turk et al. 1993), resulting in $\beta$-cell death by necrosis (Like et al. 1978). There are two streptozotocin-induced animal models of diabetes: administration of a single high dose of streptozotocin (SHDS) induces diabetes by directly destroying the $\beta$-cells, and administration of multiple low-dose streptozotocin (MLDS) induces diabetes progressively via an immune cell response directed towards the $\beta$-cells. In the MLDS model, hyperglycemia and diabetes are induced by several injections of subdiabetogenic doses, each injection resulting in a fraction of the $\beta$-cells being damaged (Kolb 1987, Kolb \& Krönke 1993), eventually leading to a local inflammation and an insulitis similar to that observed in patients with recent-onset IDDM (Like \& Rossini 1976, Rossini et al. 1978).

The aims of this present study were to determine the sensitivity of NFKB (p50)-deficient mice to both the MLDS and SHDS models of diabetes, and to establish whether isolated islets of Langerhans from p50-deficient mice were resistant to the in vitro effects of cytokines specifically, their induction of NOS and inhibitory effect on insulin secretion.

\section{Materials and Methods}

\section{Animals}

Six-to-eight-week-old $(\mathrm{B} 6 \times 129) \mathrm{F}_{2}(\mathrm{~B} 6129)$ mice homozygous for NFKB1 mutation (Sha et al. 1995) and their littermate controls were purchased from The Jackson
Laboratory (Bar Harbor, ME, USA). The mice were housed at the Inotek Corporation animal facility for 1 week before the experimental procedure was begun. All animal experiments were carried out in accordance with the guidelines published by the National Institutes of Health (1985) and with the approval of the Inotek Corporation Institutional Animal Care and Use committee.

\section{Induction of diabetes}

Two methods of inducing diabetes were utilized in this

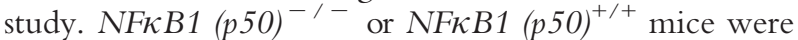
treated with either streptozotocin $(40 \mathrm{mg} / \mathrm{kg}$ dissolved in citrate buffer, $\mathrm{pH} 4.5$ ) or vehicle (citrate buffer) intraperitoneally (i.p.) for 5 consecutive days (MLDS model) (Flodstrom et al. 1999), or with streptozotocin (160 mg/ $\mathrm{kg}$ ) as a single i.p. injection (SHDS model) (Garcia Soriano et al. 2001). For the MLDS model, the blood glucose was monitored over the following 21 days using a one-touch blood glucose meter (Lifescan). Blood glucose was measured on days 1, 7, 14 and 21, from blood obtained from the tail vein. Mice treated with the single high dose of streptozotocin had their blood glucose measured daily for 4 days before being killed. Diabetes was defined as a non-fasting blood glucose concentration greater than $200 \mathrm{mg} / \mathrm{dl}$.

\section{Pancreatic content of insulin}

Pancreas samples from mice killed on day 21 (MLDS) or day 4 (SHDS) were weighed before being placed into $6 \mathrm{ml}$ of acid ethanol (ethanol: $\mathrm{H}_{2} \mathrm{O}: \mathrm{HCl}$ in the proportions 23:7:0.45) and homogenized. The pancreas was incubated for $72 \mathrm{~h}$ at $4{ }^{\circ} \mathrm{C}$ before being centrifuged $(200 \boldsymbol{g}$ for $10 \mathrm{~min}$ ) and the insulin content of the supernatant was then determined using a commercially available enzymelinked immunosorbent assay (ELISA) kit from Alpco (Windham, NH, USA). Insulin content was expressed as ng insulin/mg protein.

\section{Serum cytokine concentrations}

Blood samples were taken from mice treated with MLDS on day 21. ELISA kits that are specific against murine cytokines were used to determine cytokine concentrations in the serum. Concentrations of IL-12 (p40), IL-12 (p70) TNFa, IL-4 and IL-10 were measured using ELISA kits purchased from R \& D systems (Minneapolis, MN, USA). Plates were read at $450 \mathrm{~nm}$ with a Spectramax 250 microplate reader from Molecular Devices (Sunnyvale, CA, USA). Assays were performed according to the manufacturers' instructions.

\section{Nitrite/nitrate concentrations}

Serum or culture media nitrite/nitrate concentrations were determined by converting the nitrate to nitrite using 
the enzyme nitrate reductase, followed by addition of Griess reagent to quantify the nitrite concentration colorimetrically. The serum was diluted 1:5 in PBS before a $25 \mu \mathrm{l}$ aliquot was added to a mixture of $25 \mu \mathrm{l}$ nitrate reductase $(1 \mathrm{U} / 1.5 \mathrm{ml})$ and $25 \mu \mathrm{NADPH}(0.134 \mathrm{mg} / \mathrm{ml})$ in $40 \mathrm{mM}$ Tris, $\mathrm{pH} 7 \cdot 6$, and incubated at room temperature for $3 \mathrm{~h}$. After this period, $100 \mu \mathrm{l}$ of Griess reagent $(1: 1$ mix of $1 \%$ sulphanilamide in 5\% phosphoric acid and $0 \cdot 1 \%$ naphthyl-ethylenediamine) was added and incubated for a further $10 \mathrm{~min}$ at room temperature, then the absorbency of the samples was read at $540 \mathrm{~nm}$ with a $650 \mathrm{~nm}$ reference (Green et al. 1982). The procedure was identical for the assay of nitrite/nitrate in the culture media, except that no dilution of the samples was required, the standards were prepared in the appropriate culture media, and the plate was incubated for only $2 \mathrm{~h}$ before addition of the Griess reagent. The concentration of nitrate was determined from a standard curve of sodium nitrate and calculated as $\mu \mathrm{M}$ nitrate.

\section{Isolation and culture of islets of Langerhans}

Islets of Langerhans from both the wild-type and NFkB1deficient mice were isolated under aseptic conditions from collagenase-digested pancreata. Batches of 200 islets were cultured free-floating in RPMI 1640 medium containing $5.5 \mathrm{mM}$ glucose, penicillin $(50 \mathrm{U} / \mathrm{ml})$, streptomycin $(50 \mu \mathrm{g} / \mathrm{ml})$ and $5 \%$ fetal calf serum (vol/vol) (Gibco Brl, Life Technologies, Frederick, MD, USA) for 48 h, before being assigned to experimental groups.

\section{Cytokine treatment of the islets}

Islets were treated with IL-1 $\beta$, TNF $\alpha$ and interferon (IFN) $-\gamma$, either alone or in combination. Isolated islets were treated with human recombinant IL-1 $\beta$ (100 pM) and TNF $\alpha(100 \mathrm{pM})$ plus murine IFN- $\gamma(10 \mathrm{U} / \mathrm{ml})$, all obtained from R \& D systems, for $24 \mathrm{~h}$.

\section{Measurement of glucose-stimulated insulin release}

Islets were removed from culture and preincubated in Gey \& Gey (1936) physiological buffer containing $2 \mathrm{mM}$ glucose. The insulin secretory response was measured from groups of five islets incubated in $1 \mathrm{ml}$ buffer containing $20 \mathrm{mM}$ glucose, for $1 \mathrm{~h}$ (Green et al. 1993). At the end of the incubation, $0.4 \mathrm{ml}$ was removed and assayed for insulin using a commercially available insulin ELISA kit (Alpco). Results were expressed as ng insulin/islet per $h$.

\section{Statistical analysis}

Data are presented as mean \pm S.E.M. Statistical analysis was preformed using either $\chi^{2}$ test or Student's $t$-test, as appropriate.

\section{Results}

\section{Studies in mice treated with MLDS}

In response to MLDS, the wild-type mice responded with progressive hyperglycemia and an increased incidence of diabetes (Fig. 1), whereas the NFKB (p50)-deficient mice were fully resistant to the development of diabetes (Fig. 1) over the 21-day period of observation. The degree of insulin depletion in the pancreata of the NFKB (p50)-deficient mice was significantly attenuated compared with the response in the wild-type mice. The insulin content in wild-type mice decreased by $71 \%$ with MLDS treatment (from $73 \pm 18 \cdot 8$ to $21 \pm 4 \mathrm{ng}$ insulin/mg protein), whereas in NFKB (p50)-deficient mice the decrease was $49 \%$ (from $72 \pm 11$ to $37 \pm 5 \mathrm{ng}$ insulin/mg protein), indicating that p50 deficiency protects against the immune-cell-mediated islet cell destruction. MLDS-treated wild-type mice had an approximately twofold increase in serum nitrite/nitrate concentrations, indicative of increased formation of NO, whereas NFKB (p50)-deficient mice exhibited no increase in nitrite/nitrate concentrations (Fig. 2a). To investigate further the mechanism of protection by $N F \kappa B$ (p50) gene disruption, serum concentrations of inflammatory cytokines in mice subjected to MLDS were determined. In wild-type mice, there was an increase in serum IL-12 (p40) concentrations (Fig. 2b), but no detectable effect on IL-10 concentrations (Fig. 2c). Serum concentrations of IL-12 (p70), TNFa and IL-4 were undetectable using the available ELISA kits (not shown). In the NFKB (p50)-deficient mice treated with streptozotocin, the serum NO and IL-12 (p40) responses were abolished (Figs $2 \mathrm{a}$ and $2 \mathrm{~b}$ ). However, the basal concentrations of IL-12 (p40) found in the serum of p50-deficient mice were sixfold greater than those measured in the wild-type mice (Fig. 2b). Interestingly, we found, in contrast, that the basal serum concentrations of IL-10 in p50-deficient mice were half those found in wild-type mice (Fig. 2c), and that MLDS treatment had no effect on serum concentrations of IL-10.

\section{Studies in mice treated with SHDS}

Both wild-type and NFkB (p50)-deficient mice developed severe diabetes. Blood glucose concentrations, incidence of diabetes and pancreatic insulin depletion were $360 \pm 11 \mathrm{mg} / \mathrm{dl}, \quad 100 \%$ and $94 \%(68 \pm 8$ to $4 \pm 2 \mathrm{ng}$ insulin/mg protein) in the wild-type mice, and $305 \pm 14 \mathrm{mg} / \mathrm{dl}, \quad 100 \%$ and $97 \% \quad(73 \pm 6$ to $2 \pm 1 \mathrm{ng}$ insulin/mg protein) in the NFKB (p50)-deficient mice, at 4 days after administration of streptozotocin $(n=12$ per group). There was no effect of SHDS on serum nitrite/ nitrate concentrations in either the wild-type or the NFאB (p50)-deficient mice (data not shown). 


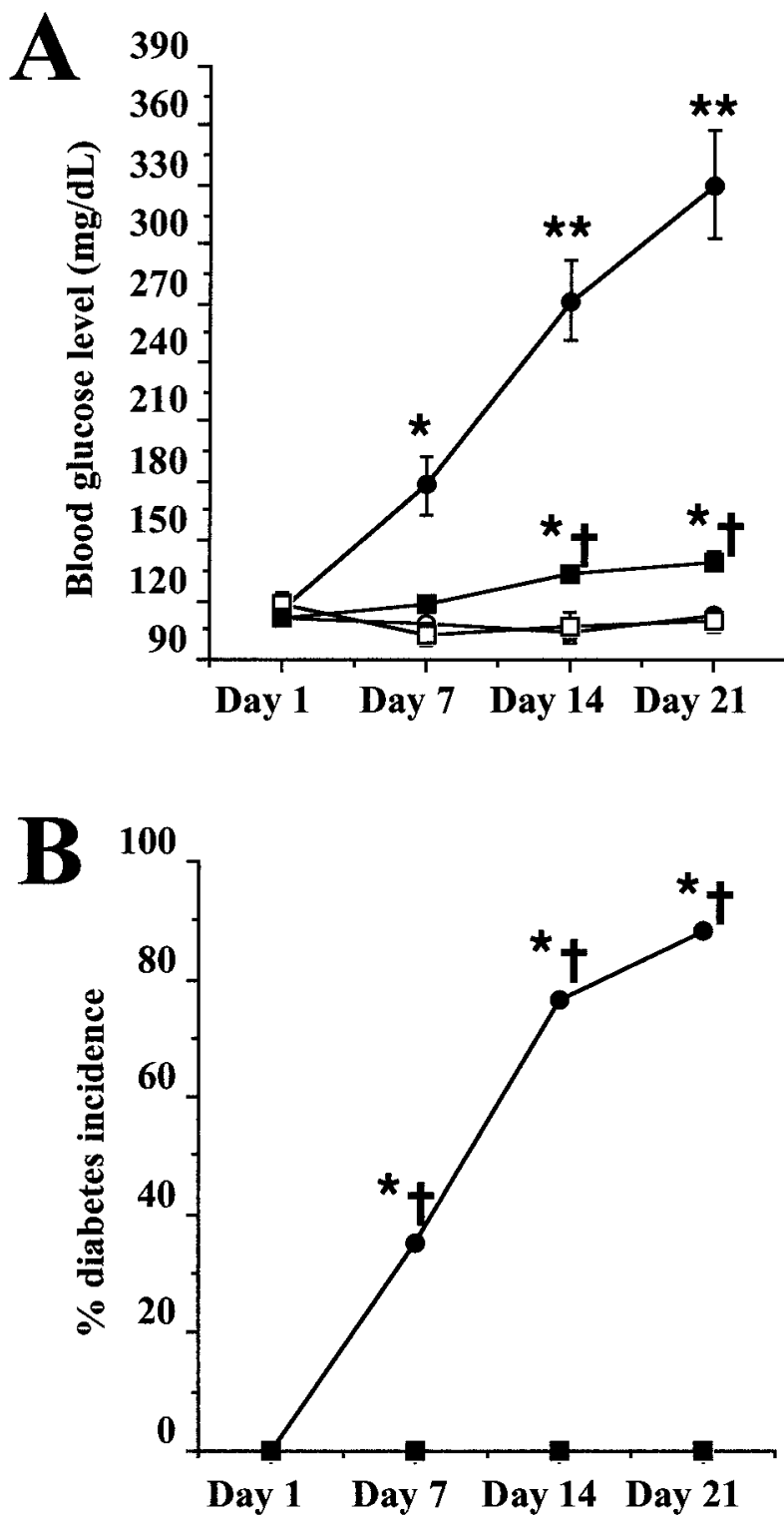

Figure $1 N F \kappa B$ (p50) gene disruption prevents multiple low-dose streptozotocin (MLDS)-induced diabetes. Blood glucose concentrations (A) and incidence of diabetes (B) in wild-type and NFKB (p50)-deficient mice with or without MLDS treatment. $\bigcirc$, Vehicle-treated wild-type mice; $\bullet$ MLDS-treated wild-type mice; $\square$, vehicle-treated p50-knockout mice; $\square$, MLDS-treated p50-knockout mice. Glycemia is expressed as mg glucose/dl and plotted as mean \pm S.E.M. ( $n=6$ for untreated mice and $n=17$ for MLDS-treated mice for each respective experimental group). The incidence of diabetes is expressed as the cumulative percentage of mice that have a blood glucose concentration greater than $200 \mathrm{mg} / \mathrm{dl} .{ }^{*} P<0 \cdot 05,{ }^{*} P<0 \cdot 01$ compared with untreated mice; $+P<0.05$ compared with $\mathrm{NF \kappa B}^{+/+}$mice treated with MLDS.

Response of islets of Langerhans exposed to cytokine treatment Islets isolated from both mouse phenotypes were exposed to a mixture of proinflammatory cytokines IL-1 $\beta$
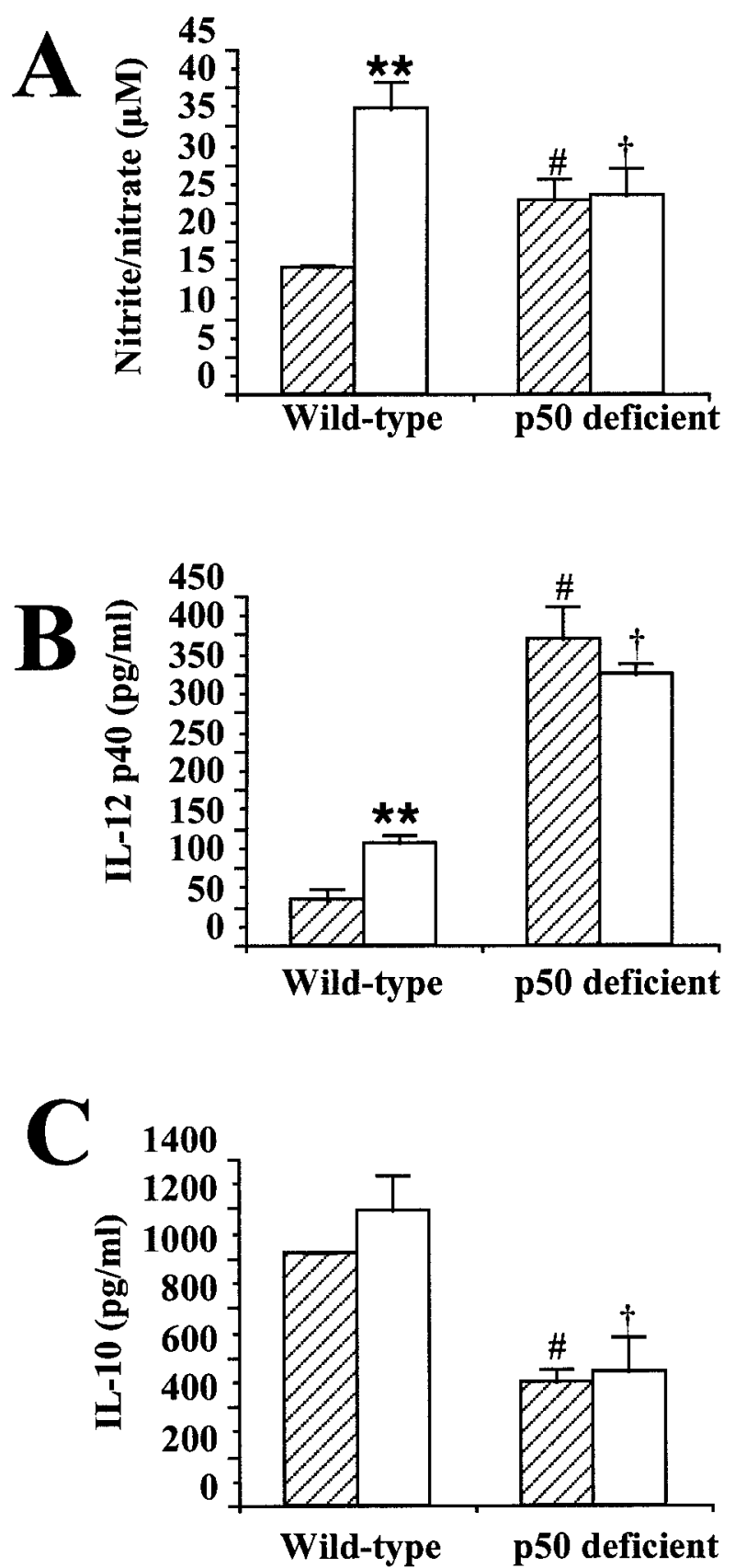

Figure $2 N F \kappa B(p 50)$ gene disruption reduces the ability of diabetes to induce $\mathrm{NO}$ and IL-12 formation. Serum concentrations of (A) nitrite/nitrate, (B) IL-12 and (C) IL-10 in control animals and at 21 days of diabetes are shown as mean \pm S.E.M. of nine untreated (vehicle-treated) mice (cross-hatched bars) or 17 MLDS-treated mice (open bars) per group. ${ }^{* *} P<0 \cdot 01$ compared with untreated mice; ${ }^{\#} P<0.05$ compared with untreated $\mathrm{NFKB}^{+/+}$mice; $+P<0 \cdot 05$ compared with $\mathrm{NFKB}^{+/+}$mice treated with streptozotocin.

$(100 \mathrm{pM}), \mathrm{TNF} \alpha(100 \mathrm{pM})$ and $\mathrm{IFN}-\gamma(10 \mathrm{U} / \mathrm{ml})$ for $24 \mathrm{~h}$. Cytokine-treated islets from wild-type mice had a compromised insulin secretory response to glucose 
stimulation, the insulin secretion in response to $20 \mathrm{mM}$ glucose being reduced from $2 \cdot 6 \pm 0 \cdot 4$ to $1 \cdot 2 \pm 0 \cdot 2 \mathrm{ng}$ insulin/islet per h $(P<0 \cdot 05)$. Similar results were obtained from cytokine-treated islets obtained from NFKB (p50)deficient mice, with a reduction in glucose-stimulated insulin release from $2 \cdot 2 \pm 0.4$ to $0.96 \pm 0.2 \mathrm{ng}$ insulin/ islet per $\mathrm{h}(P<0 \cdot 05)$. Cytokine treatment of islets isolated from wild-type mice resulted in increased $\mathrm{NO}$ formation: from $46 \pm 0 \cdot 8$ to $69 \pm 3 \cdot 4 \mathrm{pmol}$ nitrite+nitrate/islet per $24 \mathrm{~h}(P<0 \cdot 05)$. Cytokine treatment of islets from NFKB (p50)-deficient mice also significantly increased NO formation, from $39 \pm 2.6$ to $49 \pm 2.5 \mathrm{pmol} /$ islet per $24 \mathrm{~h}$ $(P<0 \cdot 05)$; however, this effect was reduced by $56 \%$ compared with the formation of $\mathrm{NO}$ in wild-type islets. Exposure of islets from either mouse phenotype to individual cytokines had no effect on either glucosestimulated insulin secretion or NO formation (data not shown).

\section{Discussion}

IDDM results from the selective destruction of the $\beta$-cell. Data obtained from animal models and diabetic patients have suggested that this destruction is mediated by the immune system (Yoon et al. 1998). The results presented here indicate that the transcription factor, NFKB, has a vital role in the cascade of events culminating in MLDSinduced diabetes in mice; more specifically, it implicates the p50 subunit as the major member of this transcription factor family responsible for development of diabetes. Our findings have indicated that the protection of $\mathrm{p} 50$ deficient mice from MLDS is due to an immune-systemrelated mechanism, rather than a direct protection of islet $\beta$-cells from damage or destruction by either streptozotocin or inflammatory cell mediators such as cytokines.

It has been reported previously that the induction of iNOS and the subsequent formation of $\mathrm{NO}$ mediate destruction of the $\beta$-cells in diabetes. The sources of $\mathrm{NO}$ include immune cells of the insulitis lesion, such as macrophages, which produce $\mathrm{NO}$ and can directly destroy pancreatic $\beta$-cells, plus indirect formation of NO from pancreatic islet cells exposed to cytokines. Islet endothelial cells (Steiner et al. 1997), duct cells (Pavlovic et al. 1999) and $\beta$-cells (Southern et al. 1990, Mabley et al. 1997) all produce $\mathrm{NO}$ after cytokine stimulation. Inhibition of $\mathrm{NO}$ formation using either a specific iNOS inhibitor (SuarezPinzon et al. 2001) or iNOS gene disruption (Flodstrom et al. 1999) renders mice more resistant to diabetes. Unlike the wild-type mice, NFKB (p50)-deficient mice show no increase in serum nitrite/nitrate concentrations, indicative of NO formation, in response to MLDS. The lack of NO formation in response to MLDS may be one reason why the p50-deficient mice are protected from developing diabetes. Interestingly, the basal concentrations of serum nitrite/nitrate were significantly greater in the knockout mice as compared with the wild-type mice, probably reflecting an increased basal production of NO. Though it is not possible to determine which cells are responsible for this NO production, these knockout mice have in their serum a depressed basal concentration of IL-10 - a cytokine known to inhibit production of NO (Cunha et al. 1992, Corraliza et al. 1995) by both inhibiting expression of the enzyme and reducing the cellular concentrations of the substrate, arginine. Therefore, it may be that some cell types of the NFKB (p50)-deficient mouse are less able to regulate their $\mathrm{NO}$ production, resulting in an increased basal production.

In vitro data have implicated $\mathrm{NO}$ in the cytokinemediated inhibitory effects on isolated rat (Southern et al. 1990, Mabley et al. 1997), mouse (Yamada et al. 1993) and human (Corbett et al. 1993, Giannoukakis et al. 2000) islets of Langerhans. NFKB has been reported to be an essential transcription factor for the induction of $\mathrm{NO}$ synthase in $\beta$-cells (Flodstrom et al. 1996) and other cell types (Forstermann \& Kleinert 1995). These observations, coupled with in vivo data, may lead to the suggestion that the NFKB (p50) mouse is essentially an iNOS-deficient mouse. However, isolated islets from NFkB (p50)deficient mice treated with cytokines produce $\mathrm{NO}$, as do macrophages isolated from NFKB (p50)-deficient mice treated with lipopolysaccharide (G Haskó \& C Szabó, unpublished observations), indicating that cells lacking the p50 subunit are still capable of expressing iNOS. Our data do suggest that NFKB (p50) may potentiate induction of NOS in islets of Langerhans, as NO formation was less in cytokine-treated p50-deficient mouse islets than in wildtype islets. This reduction in NO formation had no effect on the degree of inhibition of insulin secretion observed after cytokine treatment of p50-deficient islets - an effect which may be partly due to a recently reported NOindependent pathway of cytokine-mediated inhibition of insulin secretion (Andersson et al. 2001).

NFKB (p50)-deficient mice had no resistance to the SHDS model of diabetes, indicating that, unlike alloxan (Quan et al. 2001), streptozotocin's mechanism of direct $\beta$-cell damage and destruction is not mediated by NFKB. The decrease in the insulin content of the pancreas in p50-deficient mice treated with MLDS indicates that even subdiabetogenic doses of streptozotocin cause $\beta$-cell destruction. These observations, plus the lack of protection of islets from immune-cell mediators such as cytokines, suggest that the mechanism by which NFKB (p50)deficient mice are protected from MLDS-induced diabetes involves inhibition of activation of the immune system and subsequent $\beta$-cell functional inhibition and destruction.

It has been reported that NFKB (p50)-deficient mice have an impaired immune system and antibody responses (Sha et al. 1995). In the collagen-induced animal model of arthritis, it was noted that NFKB (p50)-deficient mice did not produce IgM antibodies and had markedly reduced $\operatorname{IgG}$ antibodies in response to an injection of collagen, and 
this was proposed as the mechanism by which p50deficient mice were completely protected from arthritis (Campbell et al. 2000). It was also found that that p50-deficient mice had a reduced $\mathrm{T}$-cell proliferative response to collagen (Campbell et al. 2000), which is consistent with previous findings of a diminished response to mitogens and altered production of cytokines by T-cells of p50-deficient mice (Sha et al. 1995, Hilliard et al. 1999). It may be that, in the absence of NFKB (p50), autoreactive T-cells may not be fully activated, with a compromised differentiation into $\mathrm{T}$ helper (Th) 1- or Th2-type cells, which in turn may inhibit development of an autoimmune disease such as diabetes. However, although none of the NFKB (p50)-deficient mice developed overt diabetes that is, a blood glucose concentration greater than $200 \mathrm{mg} /$ $\mathrm{dl}$ - four of 17 of these mice had a blood glucose concentration greater than $150 \mathrm{mg} / \mathrm{dl}$ on day 21 after MLDS treatment. Indeed, two of these mice had blood glucose concentrations greater than $170 \mathrm{mg} / \mathrm{dl}$, and this was coupled with both mice having serum nitrite/nitrate concentrations double those found in non-diabetic mice, indicating an immune-cell-mediated attack, possibly via cytokine production on the islet $\beta$-cells, inhibiting their function. Therefore, the absence of NFKB (p50) is not absolutely protective against MLDS-induced hyperglycemia, suggesting that the immune cell defects of the $\mathrm{NF \kappa B}$ (p50)-deficient mice do not fully explain the protection against IDDM, and that we must also consider other possible mechanisms.

The increased basal concentrations of the $\mathrm{p} 40$ subunit of IL-12 in the NFKB (p50)-knockout mice may provide an explanation as to why the immune system is not activated by MLDS treatment. IL-12 is a $75 \mathrm{kDa}$ heterodimeric cytokine produced from macrophages and other antigenexpressing cells. The p35 subunit is ubiquitously expressed in many cell types, whereas the p40 subunit is inducible (Trinchieri 1994). The production of biologically active recombinant IL-12 requires the expression of both the p35 and p40 subunits (Burunda 1994). The p40 subunit, however, has been shown to form a homodimer that antagonizes IL-12 activities in vitro, and hence may reflect a natural suppressor of Th1 activation in vivo (Mattner et al. 1993, Gillessen et al. 1995). Previous work has indicated that treatment of the spontaneous animal model of IDDM (the non-obese diabetic (NOD) mouse) with the IL-12 antagonist IL-12 (p40) $)_{2}$ suppressed the development of diabetes, and this protection was associated with a decreased pancreatic expression of mRNA for both iNOS and IFN- $\gamma$ (Rothe et al. 1997). The intra-islet infiltration by immune cells was also reduced. Interestingly, Rothe et al. (1997) also reported that the administration of IL-12 $(\mathrm{p} 40)_{2}$ down-regulated expression of the IL-12 (p35) subunit. Therefore, it was proposed that the IL-12 p40 homodimer suppressed the development of diabetes by reducing islet infiltration by selective down-regulation of Th1-type responses (Rothe et al. 1997). The dramati- cally increased serum concentrations of IL-12 (p40) in the NFKB (p50)-deficient mice may act as a natural antagonist to IL-12 and limit the Th1 cell response to $\beta$-cell antigens released after damage to the $\beta$-cells by streptozotocin treatment. This increased expression of IL-12 (p40) in $\mathrm{NF \kappa B}$ (p50)-deficient mice may be explained by the fact that, although most of the NFKB dimers are activators of transcription, the p50/p50 and p52/p52 homodimers repress the transcription of their target genes (Ghosh et al. 1998, Karin \& Ben-Neriah 2000). The $I L-12$ (p40) gene may be such a target.

The significantly lower basal concentrations of IL-10 in the NFKB-deficient mice are probably a result of the increased IL-12 (p40) concentrations, as these two cytokines have been shown to be reciprocally regulated, with increased concentrations of either one decreasing the concentrations of the other (Hasko \& Szabo 1999). The decreased concentration of IL-10, however, seems to have no effect on the development of diabetes in these mice, even though IL-10 has been shown to be an important regulator of the development of diabetes (Wogensen et al. 1994). Recently, adeno-associated virus vector-mediated delivery of IL-10 to female NOD mice was found to prevent the development of diabetes (Goudy et al. 2001). The authors speculated that the mechanism for this protection was that IL-10 inhibited the synthesis of a number of proinflammatory cytokines, including IFN- $\gamma$, IL-2 and TNF. It is likely that the protective effects of removing the $N F \kappa B(p 50)$ gene override any increased susceptibility caused by the resulting decrease in basal concentrations of IL-10.

The above is only one hypothesis, and recently reported data have indicated a primary role for NFKB (p50) in the expression of many genes in cytokine-treated rat islet $\beta$-cells, including such genes as ICAM, various apoptosisrelated genes, COX-2, FAS and iNOS (Cardozo et al. 2001, Heimberg et al. 2001). Although we were unable to show any protective effect of $N F \kappa B(p 50)$ gene disruption on isolated islets exposed to cytokine combinations in vitro, we assessed the functionality of the $\beta$-cells only by insulin secretory responsiveness, and did not assess viability or $\beta$-cell death. In vivo, where the concentrations of cytokines to which the $\beta$-cell is exposed may be lower, a more pronounced effect on $\beta$-cell functionality and survival may be observed after disruption of the NFאB (p50) gene.

\section{Conclusion}

We have presented evidence suggesting a pivotal role for the p50 subunit of NFKB in the pathogenesis of IDDM in the MLDS model. Other autoimmune diseases have also been shown to be dependent on NFKB (p50), including encephalomyelitis (Hilliard et al. 1999) and rheumatoid arthritis (Campbell et al. 2000). To date, NFkB blockade with NFKB decoy oligonucleotides has been shown to 
inhibit arthritis (Tomita et al. 1999) and inflammatory bowel disease (Neurath et al. 1996) in animal models. Thus the feasibility and efficacy of such strategies has already been proved. Specific blockade of NFKB (p50) subunit may potentially be an effective treatment with which to prevent human IDDM.

\section{References}

Andersson AK, Flodstrom M \& Sandler S 2001 Cytokine-induced inhibition of insulin release from mouse pancreatic beta-cells deficient in inducible nitric oxide synthase. Biochemical and Biophysical Research Communications 281 396-403.

Baeuerle PA \& Henkel T 1994 Function and activation of NF- $\mathrm{BB}$ in the immune system. Annual Review of Immunology 12 141-179.

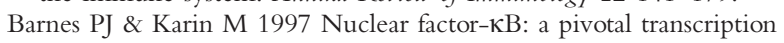
factor in chronic inflammatory diseases. New England Journal of Medicine 336 1066-1071.

Beauparlant P \& Hiscott J 1996 Biological and biochemical inhibitors of the NF-KB/Rel proteins and cytokine synthesis. Cytokine and Growth Factor Reviews 7 175-190.

Bradley LM, Asensio VC, Schioetz LK, Harbertson J, Krahl T, Patstone G, Woolf N, Campbell IL \& Sarvetnick N 1999 Isletspecific Th1, but not Th2, cells secrete multiple chemokines and promote rapid induction of autoimmune diabetes. Journal of Immunology 162 2511-2520.

Burunda MJ 1994 Interleukin-12. Journal of Lenkocyte Biology 55 280-288.

Campbell IK, Gerondakis S, O’Donnell K \& Wicks IP 2000 Distinct roles for the NF- $\mathrm{KB} 1$ ( $\mathrm{p} 50)$ and $\mathrm{c}-\mathrm{Rel}$ transcription factors in inflammatory arthritis. Journal of Clinical Investigation 105 1799-1806.

Cardozo AK, Kruhoeffer M, Leeman R, Ørntoft T \& Eizirik DL 2001 Identification of novel cytokine-induced genes in pancreatic $\beta$-cells by high-density oligonucleotide arrays. Diabetes $\mathbf{5 0} 909-920$.

Chen F, Castranova V, Shi X \& Demers LM 1999 New insights into the role of nuclear factor- $\kappa \mathrm{B}$, a ubiquitous transcription factor in the initiation of diseases. Clinical Chemistry 45 7-17.

Corbett JA, Sweetland MA, Wang JL, Lancaster JR Jr \& McDaniel ML 1993 Nitric oxide mediates cytokine-induced inhibition of insulin secretion by human islets of Langerhans. PNAS $\mathbf{9 0}$ 1731-1735.

Corraliza IM, Soler G, Eichmann K \& Modolell M 1995 Arginase induction by suppressors of nitric oxide synthesis (IL-4, IL-10 and PGE2) in murine bone-marrow-derived macrophages. Biochemical and Biophysical Research Communications 206 667-673.

Cunha FQ, Moncada S \& Liew FY 1992 Interleukin-10 (IL-10) inhibits the induction of nitric oxide synthase by interferon-gamma in murine macrophages. Biochemical and Biophysical Research Communications 182 1155-1159.

Delaney CA, Dunger AM, Di Matteo M, Cunningham JM, Green MHL \& Green IC 1995 Comparison of inhibition of glucosestimulated insulin secretion in rat islets of Langerhans by streptozotocin and methyl and ethyl nitrosoureas and methanesulphonates: lack of correlation with nitric oxide-releasing or $\mathrm{O}^{6}$-alkylating ability. Biochemical Pharmacology 50 2015-2020.

Eizirik DL, Flodstrom M, Karlsen AE \& Welsh N 1996 The harmony of the spheres: inducible nitric oxide synthase and related genes in pancreatic beta cells. Diabetologia 39 875-890.

Elsner M, Guldbakke B, Tiedge M, Munday R \& Lenzen S 2000 Relative importance of transport and alkylation for pancreatic betacell toxicity of streptozotocin. Diabetologia 43 1528-1533.

Flodstrom M, Welsh N \& Eizirik DL 1996 Cytokines activate the nuclear factor $\kappa \mathrm{B}(\mathrm{NF}-\mathrm{\kappa B})$ and induce nitric oxide production in human pancreatic islets. FEBS Letters 385 4-6.
Flodstrom M, Tyrberg B, Eizirik DL \& Sandler S 1999 Reduced sensitivity of inducible nitric oxide synthase-deficient mice to multiple low-dose streptozotocin-induced diabetes. Diabetes $\mathbf{4 8}$ 706-713.

Forstermann U \& Kleinert H 1995 Nitric oxide synthase: expression and expressional control of the three isoforms. Naunyn Schmiedebergs Archives of Pharmacology 352 351-364.

Garcia Soriano F, Virag L, Jagtap P, Szabo E, Mabley JG, Liaudet L, Marton A, Hoyt DG, Murthy KG, Salzman AL, Southan GJ \& Szabo C 2001 Diabetic endothelial dysfunction: the role of poly(ADP-ribose) polymerase activation. Nature Medicine 7 108-113.

Gey GO \& Gey MH 1936 Maintenance of human normal cells and tumour cells in continuous culture. American Journal of Cancer 27 $45-76$.

Ghosh S, May MJ \& Kopp EB 1998 NF-KB and Rel proteins: evolutionarily conserved mediators of immune responses. Annual Review of Immunology 16 225-260.

Giannoukakis N, Rudert WA, Trucco M \& Robbins PD 2000 Protection of human islets from the effects of interleukin-1 beta by adenoviral gene transfer of an ikB repressor. Journal of Biological Chemistry 275 36509-36513.

Gillessen S, Carvajal D, Ling P, Podlaski FJ, Stremlo DL, Familletti PC, Gubler U, Presky DH, Stern AS \& Gately MK 1995 Mouse interleukin-12 (IL-12) p40 homodimer: a potent IL-12 antagonist. European Journal of Immunology 25 200-206.

Goudy K, Song S, Wasserfall C, Zhang YC, Kapturczak M, Muir A, Powers M, Scott-Jorgensen M, Campbell-Thompson M, Crawford JM, Ellis TM, Flotte TR \& Atkinson MA 2001 Adeno-associated virus vector-mediated IL-10 gene delivery prevents type 1 diabetes in NOD mice. PNAS 98 13913-13918.

Grankvist K, Marklund S \& Taljedal IB 1981 Superoxide dismutase is a prophylactic against alloxan diabetes. Nature 294 158-160.

Green LC, Wagner DA, Glogowski J, Skipper PL, Wishnok JS \& Tannenbaum SR 1982 Analysis of nitrate, nitrite and $\left[{ }^{15} \mathrm{~N}\right]$ nitrate in biological fluids. Analytical Biochemistry 126 131-138.

Green IC, Delaney CA, Cunningham JM, Karmiris V \& Southern C 1993 Interleukin-1 $\beta$ effects on cyclic GMP and cyclic AMP in cultured rat islets of Langerhans - arginine-dependence and relationship to insulin secretion. Diabetologia 36 9-16.

Hasko G \& Szabo C 1999 IL-12 as a therapeutic target for pharmacological modulation in immune-mediated and inflammatory diseases: regulation of $\mathrm{T}$ helper $1 / \mathrm{T}$ helper 2 responses. British Journal of Pharmacology 127 1295-1304.

Heimberg H, Heremans Y, Jobin C, Leemans R, Cardozo AK, Darville M \& Eizirik DL 2001 Inhibition of cytokine-induced NF- $\kappa B$ activation by adenovirus-mediated expression of a NF- $\kappa B$ super-repressor prevents beta-cell apoptosis. Diabetes 50 2219-2224.

Hilliard B, Samoilova EB, Liu TS, Rostami A \& Chen Y 1999 Experimental autoimmune encephalomyelitis in NF- $\mathrm{KB}$-deficient mice: roles of NF-K B in the activation and differentiation of autoreactive T cells. Journal of Immunology 163 2937-2943.

Janssen-Heininger YM, Poynter ME \& Baeuerle PA 2000 Recent advances towards understanding redox mechanisms in the activation of nuclear factor $\mathrm{\kappa B}$. Free Radical Biology and Medicine $\mathbf{2 8}$ $1317-1327$.

Karin M \& Ben-Neriah Y 2000 Phosphorylation meets ubiquitination: the control of NF-[K]B activity. Annual Review of Immunolology 18 621-663.

Karlsson FA, Berne C, Bjork E, Kullin M, Li Z, Ma JY, Scholin A \& Zhao L 2000 Beta-cell activity and destruction in type 1 diabetes. Uppsala Journal of Medical Science 105 85-95.

Kolb H 1987 Mouse models of insulin dependent diabetes: low-dose streptozocin-induced diabetes and nonobese diabetic (NOD) mice. Diabetes and Metabolism Review 3 751-778.

Kolb H \& Kröncke K-D 1993 IDDM: lessons from the low-dose streptozotocin model in mice. Diabetes Review 1 116-126.

Like AA \& Rossini AA 1976 Streptozotocin-induced pancreatic insulitis: new model of diabetes mellitus. Science 193 415-417. 
Like AA, Appel MC, Williams RM \& Rossini AA 1978 Streptozotocin-induced pancreatic insulitis in mice. Morphologic and physiologic studies. Laboratory Investigation 38 470-486.

Mabley JG, Belin V, John N \& Green IC 1997 Insulin-like growth factor I reverses interleukin-1 beta inhibition of insulin secretion, induction of nitric oxide synthase and cytokine-mediated apoptosis in rat islets of Langerhans. FEBS Letters 417 235-238.

Mattner F, Fischer S, Guckes S, Jin S, Kaulen H, Schmitt E, Rude E \& Germann T 1993 The interleukin-12 subunit p40 specifically inhibits effects of the interleukin-12 heterodimer. European Journal of Immunology 23 2202-2208.

National Institues of Health 1985 Principles of Laboratory Animal Care. NIH publication no. 85-23 (revised). Washington: National Institues of Health.

Neurath MF, Pettersson S, Meyer zum Buschenfelde KH \& Strober W 1996 Local administration of antisense phosphorothioate oligonucleotides to the p 65 subunit of NF- $\mathrm{KB}$ abrogates established experimental colitis in mice. Nature Medicine 2 998-1004.

Pavlovic D, Chen MC, Bouwens L, Eizirik DL \& Pipeleers D 1999 Contribution of ductal cells to cytokine responses by human pancreatic islets. Diabetes 48 29-33.

Quan N, Ho E, La W, Tsai YH \& Bray T 2001 Administration of $\mathrm{NF}-\kappa \mathrm{B}$ decoy inhibits pancreatic activation of NF- $\kappa \mathrm{B}$ and prevents diabetogenesis by alloxan in mice. FASEB Journal 15 1616-1618.

Rabinovitch A \& Suarez-Pinzon WL 1998 Cytokines and their roles in pancreatic islet beta-cell destruction and insulin-dependent diabetes mellitus. Biochemistry and Pharmacology 55 1139-1149.

Rossini AA, Williams RM, Appel MC \& Like AA 1978 Complete protection from low-dose streptozotocin-induced diabetes in mice. Nature 276 182-184.

Rothe H, O'Hara RM Jr, Martin S \& Kolb H 1997 Suppression of cyclophosphamide induced diabetes development and pancreatic Th1 reactivity in NOD mice treated with the interleukin (IL)-12 antagonist IL-12(p40)2. Diabetologia 40 641-646.

Schnedl WJ, Ferber S, Johnson JH \& Newgard CB 1994 STZ transport and cytotoxicity. Specific enhancement in GLUT2expressing cells. Diabetes 43 1326-1333.

Sha WC, Liou HC, Tuomanen EI \& Baltimore D 1995 Targeted disruption of the p50 subunit of NF- $\mathrm{KB}$ leads to multifocal defects in immune responses. Cell 80 321-330.

Southern C, Schulster D \& Green IC 1990 Inhibition of insulin secretion by interleukin- $1 \beta$ and tumour necrosis factor-alpha by an
L-arginine-dependent nitric oxide generating mechanism. FEBS Letters 276 42-44.

Steiner L, Kröncke K-D, Fehsel K \& Kolb-Bachofen V 1997 Endothelial cells as cytotoxic effector cells: cytokine-activated rat islet endothelial cells lyse syngeneic islet cells via nitric oxide. Diabetologia 40 150-155.

Suarez-Pinzon WL, Mabley JG, Strynadka K, Power RF, Szabo C \& Rabinovitch A 2001 An inhibitor of inducible nitric oxide synthase and scavenger of peroxynitrite prevents diabetes development in NOD mice. Journal of Autoimmunity 16 449-455.

Tak PP \& Firestein GS 2001 NF- $\mathrm{kB}$ : a key role in inflammatory diseases. Journal of Clinical Investigation 107 7-11.

Tomita T, Takeuchi E, Tomita N, Morishita R, Kaneko M, Yamamoto K, Nakase T, Seki H, Kato K, Kaneda Y \& Ochi T 1999 Suppressed severity of collagen-induced arthritis by in vivo transfection of nuclear factor $\mathrm{\kappa B}$ decoy oligodeoxynucleotides as a gene therapy. Arthritis and Rheumatology 42 2532-2542.

Trinchieri G 1994 Interleukin-12: a cytokine produced by antigenpresenting cells with immunoregulatory functions in the generation of T-helper cells type 1 and cytotoxic lymphocytes. Blood $\mathbf{8 4}$ 4008-4027.

Turk J, Corbett JA, Ramanadham S, Bohrer A \& McDaniel ML 1993 Biochemical evidence for nitric oxide formation from streptozotocin in isolated pancreatic islets. Biochemical and Biophysical Research Communications 197 1458-1464.

Wogensen L, Lee MS \& Sarvetnick N 1994 Production of interleukin 10 by islet cells accelerates immune-mediated destruction of beta cells in nonobese diabetic mice. Journal of Experimental Medicine 179 1379-1384.

Yamada K, Otabe S, Inada C, Takane N \& Nonaka K 1993 Nitric oxide and nitric oxide synthase mRNA induction in mouse islet cells by interferon- $\gamma$ plus tumor necrosis factor- $\alpha$. Biochemical and Biophysical Research Communications 197 22-27.

Yoon JW, Jun HS \& Santamaria P 1998 Cellular and molecular mechanisms for the initiation and progression of beta cell destruction resulting from the collaboration between macrophages and T cells. Autoimmunity 27 109-122.

Received 29 January 2002

Accepted 5 February 2002 